\title{
EFEKTIFITAS PELAKSANAAN PERKULIAHAN S-1 GURU DALAM JABATANPROGRAM STUDI PENDIDIKAN BAHASA INGGRISTAHUN AKADEMIK 2010-2011
}

\author{
Eni Rosnija ${ }^{1}$ \\ Pendidikan Bahasa Inggris FKIP UNTAN \\ erosnija@yahoo.com
}

\begin{abstract}
ABSTRAK
Penelitian ini bertujuan untuk mengetahui apakah pelaksanaan perkulihan Program Pendidikan Guru Dalam Jabatan efektif . Bentuk penelitian ini adalah penelitan survey. Sampel diambil dari keseluruhan populasi.Pengumpulan data dilakukan melalui teknik kuisoner Hasil penelitian menunjukan bahwa pelaksanaan perkuliahan S-1 Guru Dalam Jabatan Program Studi Bahasa Inggris tahun 2010-2011 berjalan secara efektif.
\end{abstract}

Kata Kunci: Efektifitas dan perkuliahan.

\section{Latar Belakang}

Di dalam Undang-Undang No.20 tahun 2003 pasal 5 ayat (1) disebutkan bahwa setiap warga negara mempunyai hak yang sama memepoleh pendidikan yang bermutu (berkualitas) Artinya adalah pendidikan yang berkualitas perlu diupayakan untuk memenuhi hak setiap warga Negara. Guru adalah salah salah satu warga Negara yang mempunyai hak untuk mendapatkan pendidikan yang layak tersebut. Salah satunya adalah dengan memberi kesempatan kepada guru untuk meningkatkan kualifikasinya.

Seiring dengan hal tersebut maka pemerintah melalui Undang-Undang Guru dan Dosen tahun 2005 menegaskan bahwa guru wajib memiliki kualifikasi akademik, kompetensi, sertifikat pendidik, sehat jasmani dan rohani,serta memiliki kemampuan untuk mewujudkan tujuan pendidikan nasional. Kualifikasi akademik sebagaimana tersebut diperoleh melalui pendidikan tinggi program sarjana atau program diploma empat, sedangkan kompetensi guru sebagaimana

\footnotetext{
${ }^{1}$ Eni Rosnija adalah dosen Pendidikan Bahasa Inggris FKIP Untan
} 
dimaksud meliputi kompetensi pedagogik, kompetensi kepribadian, kompetensi sosial, dan kompetensi profesional yang diperoleh melalui pendidikan profesi.

Diantara hal yang positif berkaitan dengan undang-undang tesebut adalah perhatian terhadap guru mulai dari kesejahteraannya hingga kualitasnya. Harapan ke depan guru akan lebih professional dan sejahtera sehingga mempunyai kualitas yang lebih baik dalam mendidik dan mengajar peserta didik. Guru yang professional akan berpengaruh besar dalam kulaitas pengembangan SDM. (Ali,2009:119) Undang-undang tesebut juga mengisyaratkan perlunya upaya peningkatan kualitas pendidikan guru melalui peningkatan kualifikasi guru. Implementasi dari hal tesebut adalah di bukanya Program Pendidikan Guru Dalam Jabatan. Program ini bertujuan untuk meningkatkan kualitas guru dalam pembelajaran. Jika guru berkualitas maka pembelajaranpun diharapkan akan berkualitas pula. Hal ini tentu berdampak pada mutu lulusan yang dihasilkan kelak.

Penekanan Pendidkan Guru Dalam Jabatan adalah agar guru dalam menjalankan tugasnya dapat meningkatkan efektifitas mengajarnya, mengatasi persoalan-persoalan praktis dalam pengelolaan kegiatan pembelajaran dan meningkatkan kepekaan guru terhadap perbedaan individual para siswa yang dihadapi.

Sehubungan dengan pelaksanaan Pendidikan Guru Dalam Jabatan maka dipandang perlu untuk melihat efektifitas dari pelaksaan program tersebut terutama yang berkaitan dengan perkuliahan, khususnya di Program Studi Bahasa Inggris untuk tahun akademik 2010-2011. Efektifitas yang dimaksud adalah untuk melihat apakah pelaksanaan perkuliahan yang dilakukan sudah sesuai dengan tujuan yang ditetapkan.

Adapun tujuan dari program pendidikan guru dalam jabatan adalah untuk mendukung upaya percepatan peningkatan kualifikasi akademik bagi guru dalam jabatan sesuai dengan persyaratan yang tertuang dalam Undang-Undang Republik Indonesia Nomor 14 Tahun 2005 tentang Guru dan Dosen.

Kegiatan perkuliahan Program Guru Dalam Jabatan berupa tatap muka yang merupakan proses interaksi langsung dan terjadwal antara dosen dan mahasiswa dalam mencapai tujuan/kompetensi pada masing-masing mata kuliah, terutama mata kuliah yang mempersyaratkan adanya kegiatan praktik atau praktikum, atau mata kuliah lain yang menurut pertimbangan pihak penyelenggara harus dilaksanakan melalui perkuliahan tatap muka. 


\section{Metodologi}

Bentuk penelitian ini adalah penelitan survey yaitu penelitian yang dilakukan untuk untuk memahami tentang karakteristik dari seluruh kelompok yang hendak diteliti atau populasi dengan meneliti sebagian (subset) dari kelompok populasi tersebut yang selanjutnya disebut dengan sampel. Populasi dalam penelitian ini adalah semua mahasiswa Program S1 Guru dalam Jabatan, program studi Bahasa Inggris yang terdaftar pada tahun akademik 2010201.Sampel diambil dari keseluruhan populasi.Pengumpulan data dilakukan melalui teknik kuisoner. Adapun instrumen penelitian sebagai berikut.

Tabel Instrumen Penelitian Perkuliahan

\begin{tabular}{|l|l|}
\hline No. & \multicolumn{1}{|c|}{ Unit Analisis } \\
\hline 1. & Jumlah perkuliahan \\
\hline 2. & Lama perkuliahan sesuai bobot sks \\
\hline 3. & Waktu perkuliahan \\
\hline 4. & Mediasi perkuliahan \\
\hline 5. & Pemanfaatan media dan teknologi dalam perkuliahan \\
\hline 6. & Tersedianya bahan ajar perkuliahan \\
\hline 7. & Adanya proses perkuliahan mandiri dengan tutorial \\
\hline 8. & Adanya proses perkuliahan mandiri tanpa tutorial \\
\hline 9. & Adanya kegiatan praktek dalam perkuliahan \\
\hline 10. & Adanya penilaian hasil perkuliahan \\
\hline
\end{tabular}

\section{Hasil Penelitian}

Melalui kuisioner yang telah diberikan kepada peserta, didapat hasil sebagai berikut:

\begin{tabular}{|l|l|c|c|c|c|c|}
\hline No. & \multicolumn{1}{|c|}{ Penyataan } & $\begin{array}{c}\text { Sangat } \\
\text { setuju }\end{array}$ & Setuju & Netral & $\begin{array}{c}\text { Tidak } \\
\text { setuju }\end{array}$ & $\begin{array}{c}\text { Sangat } \\
\text { tidak } \\
\text { setuju }\end{array}$ \\
\hline 1 & $\begin{array}{l}\text { Jumlah } \\
\text { perkuliahan } \\
\text { sebanyak 12 kali } \\
\text { pertemuan }\end{array}$ & 8 & 5 & 2 & 1 & - \\
\hline & & $50 \%$ & $31.25 \%$ & $12.5 \%$ & $6.25 \%$ & 0 \\
\hline
\end{tabular}


Dari pernyataan di atas, jawaban dari peserta adalah sebanyak $50 \%$ peserta menyatakan sangat setuju, $31.25 \%$ menyatakan setuju, $12.5 \%$ menyatakan netral dan sebanyak $6.25 \%$ menyatakan tidak setuju dengan pernyataan pertama tentang jumlah perkuliahan sebanyak 12 kali pertemuan.

\begin{tabular}{|l|l|l|l|l|l|l|}
\hline No. & \multicolumn{1}{|c|}{ Penyataan } & $\begin{array}{c}\text { Sangat } \\
\text { setuju }\end{array}$ & Setuju & Netral & \multicolumn{1}{|c|}{$\begin{array}{c}\text { Tidak } \\
\text { setuju }\end{array}$} & $\begin{array}{c}\text { Sangat } \\
\text { tidak } \\
\text { setuju }\end{array}$ \\
\hline 2 & $\begin{array}{l}\text { Lama perkuliahan } \\
\text { sesuai dengan } \\
\text { bobot sks (1 sks }= \\
50 \text { menit) }\end{array}$ & 6 & 8 & - & 2 & - \\
\hline & & $37.5 \%$ & $50 \%$ & 0 & $12.5 \%$ & 0 \\
\hline
\end{tabular}

Dari pernyataan di atas, jawaban dari peserta adalah sebanyak 37.5\% peserta menyatakan sangat setuju, 50\% menyatakan setuju dan sebanyak $12.5 \%$ menyatakan tidak setuju dengan pernyataan kedua tentang lama perkuliahan sesuai dengan bobot sks $(1 \mathrm{sks}=50$ menit $)$

\begin{tabular}{|l|l|l|l|l|l|c|}
\hline No. & \multicolumn{1}{|c|}{ Penyataan } & $\begin{array}{c}\text { Sangat } \\
\text { setuju }\end{array}$ & Setuju & Netral & $\begin{array}{c}\text { Tidak } \\
\text { setuju }\end{array}$ & $\begin{array}{c}\text { Sangat } \\
\text { tidak } \\
\text { setuju }\end{array}$ \\
\hline 3 & $\begin{array}{l}\text { Waktu } \\
\text { perkuliahan } \\
\text { dilakukan saat } \\
\text { libur sekolah }\end{array}$ & 14 & 2 & - & - & - \\
\hline & & $87.5 \%$ & $12.5 \%$ & 0 & 0 & 0 \\
\hline
\end{tabular}

Dari pernyataan di atas, jawaban dari peserta adalah sebanyak $87.5 \%$ peserta menyatakan sangat setuju, dan $12.5 \%$ menyatakan setuju dengan pernyataan ketiga tentang waktu perkuliahan dilakuakan saat libur sekolah.

\begin{tabular}{|l|l|c|c|c|c|c|}
\hline No. & Penyataan & $\begin{array}{c}\text { Sangat } \\
\text { setuju }\end{array}$ & Setuju & Netral & $\begin{array}{c}\text { Tidak } \\
\text { setuju }\end{array}$ & $\begin{array}{c}\text { Sangat } \\
\text { tidak } \\
\text { setuju }\end{array}$ \\
\hline 4 & adanya & - & - & - & 3 & 13 \\
\hline
\end{tabular}




\begin{tabular}{|l|l|l|l|l|l|l|}
\hline & $\begin{array}{l}\text { perkuliahan } \\
\text { termediasi }\end{array}$ & & & & & \\
\hline & & 0 & 0 & 0 & $18.75 \%$ & $81.25 \%$ \\
\hline
\end{tabular}

Dari pernyataan di atas, jawaban dari peserta adalah sebanyak $18.75 \%$ menyatakan tidak setuju dan $81.25 \%$ menyatakan sangat tidak setuju dengan pernyataan keempat tentang adanya perkuliahan termediasi.

\begin{tabular}{|l|l|c|c|c|c|c|}
\hline No. & Penyataan & $\begin{array}{c}\text { Sangat } \\
\text { setuju }\end{array}$ & Setuju & Netral & $\begin{array}{c}\text { Tidak } \\
\text { setuju }\end{array}$ & $\begin{array}{c}\text { Sangat } \\
\text { tidak } \\
\text { setuju }\end{array}$ \\
\hline 5 & $\begin{array}{l}\text { adanya } \\
\text { pemanfaatan } \\
\text { media dan } \\
\text { teknologi } \\
\text { dalam } \\
\text { perkuliahan. }\end{array}$ & 13 & 3 & - & - & - \\
\hline & & $81.25 \%$ & $18.75 \%$ & 0 & 0 & 0 \\
\hline
\end{tabular}

Dari pernyataan di atas, jawaban dari peserta adalah sebanyak $81.25 \%$ menyatakan sangat setuju dan $18.75 \%$ menyatakan setuju dengan pernyataan kelima tentang adanya pemanfaatan media dan teknologi dalam perkuliahan.

\begin{tabular}{|l|l|c|c|c|c|c|}
\hline No. & Penyataan & $\begin{array}{c}\text { Sangat } \\
\text { setuju }\end{array}$ & Setuju & Netral & $\begin{array}{c}\text { Tidak } \\
\text { setuju }\end{array}$ & $\begin{array}{c}\text { Sangat } \\
\text { tidak } \\
\text { setuju }\end{array}$ \\
\hline 6 & $\begin{array}{l}\text { Tersedianya } \\
\text { bahan ajar } \\
\text { perkuliahan }\end{array}$ & 11 & 5 & - & - & - \\
\hline & & $68.75 \%$ & $31.25 \%$ & 0 & 0 & 0 \\
\hline
\end{tabular}

Dari pernyataan di atas, jawaban dari peserta adalah sebanyak $81.25 \%$ peserta menyatakan sangat setuju, dan $18.75 \%$ menyatakan setuju dengan pernyataan keenam tentang tersedianya bahan ajar perkuliahan.

\begin{tabular}{|c|c|c|c|c|c|c|}
\hline No. & Penyataan & $\begin{array}{c}\text { Sangat } \\
\text { setuju }\end{array}$ & Setuju & Netral & $\begin{array}{c}\text { Tidak } \\
\text { setuju }\end{array}$ & $\begin{array}{c}\text { Sangat } \\
\text { tidak } \\
\text { setuju }\end{array}$ \\
\hline
\end{tabular}




\begin{tabular}{|l|l|c|c|c|c|c|}
\hline 7 & $\begin{array}{l}\text { Adanya proses } \\
\text { perkuliahan } \\
\text { mandiri } \\
\text { dengan } \\
\text { tutorial }\end{array}$ & 2 & 6 & 1 & 2 & 5 \\
\hline & & $12.5 \%$ & $37.5 \%$ & $6.25 \%$ & $12.5 \%$ & $31.25 \%$ \\
\hline
\end{tabular}

Dari pernyataan di atas, jawaban dari peserta adalah sebanyak $12.5 \%$ peserta menyatakan sangat setuju, 37.5\% menyatakan setuju, $6.25 \%$ menyatakan netral, $12.5 \%$ menyatakan tidak setuju, dan sebanyak $31.25 \%$ menyatakan sangat tidak setuju dengan pernyataan ketujuh tentang adanya proses perkuliahan mandiri dengan tutorial.

\begin{tabular}{|l|l|c|c|c|c|c|}
\hline No. & Penyataan & $\begin{array}{c}\text { Sangat } \\
\text { setuju }\end{array}$ & Setuju & Netral & $\begin{array}{c}\text { Tidak } \\
\text { setuju }\end{array}$ & $\begin{array}{c}\text { Sangat } \\
\text { tidak } \\
\text { setuju }\end{array}$ \\
\hline 8 & $\begin{array}{l}\text { Adanya proses } \\
\text { perkuliahan } \\
\text { mandiri tanpa } \\
\text { tutorial }\end{array}$ & 3 & - & - & 5 & 8 \\
\hline & & $18.75 \%$ & 0 & 0 & $31.25 \%$ & $50 \%$ \\
\hline
\end{tabular}

Dari pernyataan di atas, jawaban dari peserta adalah sebanyak $18.75 \%$ peserta menyatakan sangat setuju, $31.25 \%$ menyatakan tidak setuju, dan sebanyak $50 \%$ menyatakan sangat tidak setuju dengan pernyataan kedelapan tentang adanya proses perkuliahan mandiri tanpa tutorial.

\begin{tabular}{|l|l|c|c|c|c|c|}
\hline No. & Penyataan & $\begin{array}{c}\text { Sangat } \\
\text { setuju }\end{array}$ & Setuju & Netral & $\begin{array}{c}\text { Tidak } \\
\text { setuju }\end{array}$ & $\begin{array}{c}\text { Sangat } \\
\text { tidak } \\
\text { setuju }\end{array}$ \\
\hline 9 & $\begin{array}{l}\text { Adanya } \\
\text { kegiatan } \\
\text { praktek dalam } \\
\text { perkuliahan }\end{array}$ & 7 & 4 & 3 & 2 & - \\
\hline & & $43.75 \%$ & $25 \%$ & $18.75 \%$ & $12.5 \%$ & 0 \\
\hline
\end{tabular}


Dari pernyataan di atas, jawaban dari peserta adalah sebanyak $43.75 \%$ peserta menyatakan sangat setuju, 25\% menyatakan tidak setuju, $18.75 \%$ menyatakan netral dan sebanyak $12.5 \%$ menyatakan sangat tidak setuju dengan pernyataan kesembilan tentang adanya kegiatan praktek dalam perkuliahan.

\begin{tabular}{|c|l|c|c|c|c|c|}
\hline No. & Penyataan & $\begin{array}{c}\text { Sangat } \\
\text { setuju }\end{array}$ & Setuju & Netral & $\begin{array}{c}\text { Tidak } \\
\text { setuju }\end{array}$ & $\begin{array}{c}\text { Sangat } \\
\text { tidak } \\
\text { setuju }\end{array}$ \\
\hline 10 & $\begin{array}{l}\text { Adanya } \\
\text { penilaian } \\
\text { hasil } \\
\text { perkuliahan }\end{array}$ & 10 & 4 & 2 & - & - \\
\hline & & $62.5 \%$ & $25 \%$ & $12.5 \%$ & 0 & 0 \\
\hline
\end{tabular}

Dari pernyataan di atas, jawaban dari peserta adalah sebanyak $62.5 \%$ peserta menyatakan sangat setuju, 25\% menyatakan setuju, dan $12.5 \%$ menyatakan netral dengan pernyataan kesepuluh tentang adanya penilaian hasil perkuliahan.

\section{Kesimpulan dan Saran}

\section{Kesimpulan}

Melalui hasil kuesioner atau angket tersebut di atas, dapat ditarik beberapa kesimpulan, diantaranya sebagai berikut:

1. Para peserta hampir sebagian besar menyatakan setuju dengan perkuliahan sebanyak 12 kali pertemuan, hal tersebut ditunjukkan dengan jawaban peserta adalah sebanyak $50 \%$ peserta menyatakan sangat setuju, $31.25 \%$ menyatakan setuju, meskipun adapula sebanyak $12.5 \%$ menyatakan netral dan $6.25 \%$ menyatakan tidak setuju.

2. Para peserta hampir sebagian besar menyatakan setuju dengan lama perkuliahan dengan bobot sks $(1 \mathrm{sks}=50$ menit $)$, hal tersebut ditunjukkan dengan jawaban peserta adalah sebanyak $37.5 \%$ peserta menyatakan sangat setuju, $50 \%$ menyatakan setuju, meskipun $12.5 \%$ menyatakan tidak setuju.

3. Para peserta menyatakan setuju dengan waktu perkuliahan dilakukan saat libur sekolah, hal tersebut ditunjukkan dengan jawaban peserta adalah sebanyak $87.5 \%$ peserta menyatakan sangat setuju dan $12.5 \%$ menyatakan setuju. 
4. Para peserta menyatakan tidak setuju adanya perkuliahan termediasi, hal tersebut ditunjukkan dengan jawaban peserta adalah sebanyak $18.75 \%$ peserta menyatakan tidak setuju dan $81.5 \%$ menyatakan sangat tidak setuju.

5. Para peserta menyatakan setuju dengan adanya penggunaan media dan teknologi pendukung pengajaran, hal tersebut ditunjukkan dengan jawaban dari peserta adalah sebanyak $81.25 \%$ peserta menyatakan sangat setuju dan $18.75 \%$ menyatakan setuju. Begitu pula halnya dengan penggunaan bahan ajar, sebanyak $68.75 \%$ peserta menyatakan sangat setuju dan $31.25 \%$ menyatakan setuju dengan tersedianya bahan ajar perkuliahan.

6. Jawaban yang beragam ditunjukkan oleh peserta dalam menjawab pernyataan tentang proses perkuliahan, yakni dengan tutorial, sebanyak $12.5 \%$ peserta menyatakan sangat setuju, $37.5 \%$ menyatakan setuju, $6.25 \%$ menyatakan netral, $12.5 \%$ menyatakan tidak setuju, dan sebanyak $31.25 \%$ menyatakan sangat tidak setuju. Adapun proses perkuliahan tanpa tutorial, jawaban dari peserta adalah sebanyak $18.75 \%$ peserta menyatakan sangat setuju, $31.25 \%$ menyatakan tidak setuju, dan sebanyak $50 \%$ menyatakan sangat tidak setuju.

7. Peserta memiliki jawaban yang beragam tentang pernyataan adanya kegiatan praktek dalam perkuliahan, adalah sebanyak $43.75 \%$ peserta menyatakan sangat setuju, 25\% menyatakan setuju, 18.75 menyatakan netral dan sebanyak $12.5 \%$ menyatakan tidak setuju.

8. Para peserta hampir sebagian besar menyatakan setuju dengan adanya penilaian hasil perkuliahan, hal ini dapat dilihat yakni sebanyak $62.5 \%$ peserta menyatakan sangat setuju ,25\% menyatakan setuju dan $12.5 \%$ menyatakan netral.

9. Jika dilihat dari semua jawaban kuesioner tersebut di atas, dapat ditarik kesimpulan pelaksanaan perkuliahan S-1 Guru Dalam Jabatan Program Studi Bahasa Inggris tahun 2010-2011 berjalan secara efektif.

\section{Saran}

1. Pelaksanaan perkuliahan tetap dipertahankan sesuai ketentuan yaitu sebanyak dua belas kali dan pada saat sekolah libur.

2. Pelaksanaan perkuliahan dengan sistem toturial tetap diteruskan.

3. Perkuliahan termediasi perlu ditinjau ulang. 


\section{Daftar Pustaka}

Ali, Mohammad (2009). Pendidikan Untuk Pembangunan Nasional Menuju Bangsa Indonesia yang Mandiri dan Berdaya Saing Tinggi. Jakarta : Imtima.

Borg, Walter R.(1983). Educational Research. New York: Longman.

Cresswell, John W. (2008). Educational Research.New Jersey: Pearson.

Dornyei, Zoltan. (2003). Questionnaires in Second Language Research.London, Lawrence Erlbaum Association.

Gie, The Liang. (1989). Ensiklopedi Administrasi. Jakarta: PT. Air Agung Putra. Kamus Besar Bahasa Indonesia (2002). Jakarta: Gita Media Press.

Oxford University. (2001). Concise Oxford Dictionary, Tenth Edition. [CDROM]. Oxford: OxfordUniversityPress.

Oxford University. (2003). Oxford Learner's Pocket Dictionary, Third Edition. Oxford: Oxford University Press.

Pedoman Teknis (Rambu-Rambu )Penyelenggaraan Pogram Sarjana

Kependidikan bagi Guru dalam Jabatan, http:/ /www.dikti.go.id dan http://www.kemdiknas.go.id/

Steers, Richard M. et al. (1985). Efektivitas Organisasi. Jakarta: Erlangga. 


\section{KUESIONER PENELITIAN}

Efektivitas Pelaksanaan Perkuliahan S-1 Guru Dalam Jabatan

Program Studi Bahasa Inggris Tahun 2010 - 2011

Nama:

Isilah dengan memberi tanda $(\sqrt{ })$ pada kolom yang tersedia.

\begin{tabular}{|c|l|l|l|l|l|l|}
\hline No. & \multicolumn{1}{|c|}{ Pernyataan } & $\begin{array}{l}\text { Sangat } \\
\text { Setuju }\end{array}$ & Setuju & Netral & $\begin{array}{c}\text { Tidak } \\
\text { Setuju }\end{array}$ & $\begin{array}{c}\text { Sangat } \\
\text { Tidak } \\
\text { Setuju }\end{array}$ \\
\hline 1. & $\begin{array}{l}\text { Jumlah perkuliahan } \\
\text { sebanyak } 12 \text { kali pertemuan }\end{array}$ & & & & & \\
\hline 2. & $\begin{array}{l}\text { Lama perkuliahan sesuai } \\
\text { dengan bobot sks (1 sks }=50 \\
\text { menit) }\end{array}$ & & & & & \\
\hline 3. & $\begin{array}{l}\text { Waktu perkuliahan dilakukan } \\
\text { saat libur sekolah }\end{array}$ & & & & & \\
\hline 4. & $\begin{array}{l}\text { Adanya perkuliahan } \\
\text { termediasi }\end{array}$ & & & & & \\
\hline 5. & $\begin{array}{l}\text { Adanya pemanfaatan media } \\
\text { dan teknologi dalam } \\
\text { perkuliahan }\end{array}$ & & & & & \\
\hline 6. & $\begin{array}{l}\text { Tersedianya bahan ajar } \\
\text { perkuliahan }\end{array}$ & & & & & \\
\hline 7. & $\begin{array}{l}\text { Adanya proses perkuliahan } \\
\text { mandiri dengan tutorial }\end{array}$ & & & & & \\
\hline 8. & $\begin{array}{l}\text { Adanya proses perkuliahan } \\
\text { mandiri tanpa tutorial }\end{array}$ & & & & & \\
\hline 9. & $\begin{array}{l}\text { Adanya kegiatan praktek } \\
\text { dalam perkuliahan }\end{array}$ & & & & & \\
\hline 10 & $\begin{array}{l}\text { Adanya penilaian hasil } \\
\text { perkuliahan }\end{array}$ & & & & & \\
\hline
\end{tabular}

Terima kasih atas waktu dan kerjasamanya. 